International Journal of Instruction

e-ISSN: 1308-1470 • www.e-iji.net

Article submission code:

20191210060742

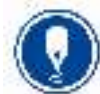

January $2021 \bullet$ Vol.14, No.1

p-ISSN: 1694-609X

pp. 181-198

Received: $10 / 12 / 2019$

Revision: 13/06/2020
Accepted: 02/07/2020

OnlineFirst:11/10/2020

\title{
Implementation of Project-Based Learning Model and Workforce Character Development for the 21st Century in Vocational High School
}

\section{Dwi Agus Sudjimat}

Dr., Universitas Negeri Malang, Malang, Indonesia,dwi.agus.ft@um.ac.id

\section{Amat Nyoto}

Dr., Universitas Negeri Malang, Malang, Indonesia, amat_nyoto61@yahoo.com

\section{Maftuchin Romlie}

Master, Universitas Negeri Malang, Malang, Indonesia, maftuchinromlie@yahoo.co.id

$$
\mid
$$

This study examines the implementation of the Project-based learning model (PjBL) model and 21st-century workforce character development in Vocational High School (VHS). It is based on the Mechanical Engineering Expertise Program as part of revitalization proposed by the Presidential Instruction Number 9 in 2016. The study used both quantitative and qualitative techniques with a sequential explanatory strategy in eleven public and private VHSs in East Java, Indonesia. Vocational teachers were used as the primary data sources. The quantitative study described the planning of the project and the implementation of the PjBL model, as well as its evaluation using structured and unstructured questionnaires. The qualitative analysis deepened and detailed the quantitative findings on the project planning process and implementation syntax. This was achieved through in-depth interviews, observation of the learning process and analysis of various learning documents, including: lesson plans, job sheets, project proposals, and student reports. The results showed that the project is planned by vocational teachers starting with simple to complex workpieces. Also, the implementation can be classified into three, including the pre-PjBL, the PjBL with a simple project, and the model with a real or complex project. The evaluation includes process and product assessment. There are ten 21st century workforce characters developed and integrated into the implementation of the model.

Keywords: project-based learning, 21st-century workforce character, mechanical engineering, vocational high school, character development

\section{INTRODUCTION}

Revitalization of vocational high schools (VHS) improves the quality of human resources by enhancing the quality of learning, laboratory facilities, and collaboration with industries. The program is based on the learning standard that emphasizes the 
implementation of discovery/inquiry, problem-based, and project-based learning models depending on each course and expertise program (Regulation of the Minister of Education and Culture Number. 22 Year, 2016). For vocational education which emphasizes the integration of various disciplines and practical abilities based on industry needs, project-based learning is the most appropriate model (Chiang \& Lee, 2016; Yudiono, Pramono, \& Basyirun, 2019). Various studies show that PjBL improves the quality of vocational education (Sukamta, Florentinus, Ekosiswoyo, \& Martono, 2018). It enhances student involvement, motivation, and attitudes in engineering learning (Viswambaran \& Shafeek, 2019; Basilotta Gómez-Pablos, Martín del Pozo, \& García-Valcárcel Muñoz-Repiso, 2017). Furthermore, PjBL improves essential skills, such as collaboration, communication, and critical and creative thinking (Larmer \& Mergendoller, 2010; Allison, 2018; Samsudi et al. 2019deepened).

$\mathrm{PjBL}$ is a learning strategy that involves the students in complex activities with several stages and relatively long duration, such as one full semester (Han \& Bhattacharya, 2010). It is a student-centered and collaborative instructional approach that encourages students to solve a problem by creating an end product (Allison, 2018). In this approach, learning is organized around the project and engages students in authentic situations to explore and apply the knowledge gained to complex problems relevant to their professional practice (Hârtescu, 2014). Generally, the project directs the students to pick and organize the learning activity, as well as to research and synthesize information (Han \& Bhattacharya, 2010). However, there is no basic standard to define a project in $\mathrm{PjBL}$. The definition can be identified and agreed upon in a specific program to make it diverse based on the scope (Aalborg University, 2010). According to Aalborg University (2010), a project is a complex activity that requires analysis. It can be planned and managed, involves new subjects, consists of complex assignments, and has to be conducted in a schedule. On a small scale, a project only exists within one scientific scope. In contrast, a project can be multidisciplinary on a large scale with various disciplines and professional personnel and teams (Mills \& Treagust, 2003a).

There are four project categories in engineering learning (Al-sharif, 2015). A practical project requires a workshop or laboratory, such as planning a simple electronic circuit, designing a mechanical system to calibrate devices, or testing measuring instruments. A visit/survey project requires students to visit industries or research institutions, for example, to observe pneumatic and hydraulic systems and engineering material testing. The students are eventually asked to write reports on the visitation. The programming projects involve making programing code from software in engineering. Lastly, a theoretical project increases the in-depth understanding of students through research and report writing.

Implementation of PjBL in VHS covers three essential components, including project planning, implementation, and evaluation (Zhang, 2013). Project planning can be performed in three ways: (a) project selection, (b) project modification, and (c) finishing the industry project. Project selection involved real projects selected by teachers or by surveying the industry to obtain topics relevant to mechanical engineering. In case the industrial project is vast, the teachers modify the project according to the 
implementation and learning durations in school. They could divide the project from the industry into sub-projects for implementation based on the learning duration in school (Zhang, 2013). Limited studies have examined the characteristics of projects planned by VHS teachers and how industries are involved.

Project implementation in school is divided into 3 stages, including (a) project introduction, (b) sub-project implementation, and (c) sub-project integration (Zhang, 2013). According to Zhang (2013), all stages can be formulated into the PjBL syntax. Waras (2009) stated that PjBL syntax consists of six steps consist of searching, solving, designing, producing/creating, evaluating, and sharing. Similar syntax is proposed by Yudiono, Pramono, \& Bsyirun (2019) with five steps, including (1) product determination, (2) product analysis and identification, (3) design of the production process, (4) product development, and (5) product evaluation. This is in line with Prince $\&$ Felder (2006), which stated that the project starts with an assignment to implement one or more tasks to create a final product, and ends with a written or oral report summarizing the procedure used and present the outcome. A more operational syntax has seven steps, including: formulating the expected learning outcome, understanding the teaching materials, skills training, designing the project theme, making the project proposal, executing the tasks of projects, and presentation of the project implemented in VHS. The results show that PjBL increases meaningful learning activities and productive competence of students (Jalinus, Nabawi, \& Mardin, 2017).

In the evaluations of the PjBL, teachers should conduct a process and summative evaluation (Zhang, 2013). Process evaluation refers to the assessment of the implementation process. In the summative evaluation, the outcome of the project is evaluated through the combination of student self-evaluation, group, and teacher evaluation results. Students with extraordinary accomplishments are appreciated while weaknesses addressed (Zhang, 2013). This means that the involvement of students in summative evaluation is important in the implementation of the PjBL model.

Apart from improving the technical skills of the students, PjBL implementation in VHS enhances soft skills related to the $21^{\text {st }}$-century workforce character. There are three essential workforce skills for the $21^{\text {st }}$ century, including (1) essential skills, such as the ability to read, write, mathematics, communication (2) thinking ability, including creative thinking, decision making, problem-solving, visualizing, learning, and reasoning, and (3) personal quality, such as the individual responsibility, confidence, socializing skill, self-management, and integrity (Secretary's Commission on Achieving Necessary Skills, 2000). Workforce character development for the $21^{\text {st }}$ century also refers to the generic skills development in some countries, such as Australia, Canada, USA, and UK (Conference Board of Canada, 2000; National Centre for Vocational Education Research (NCVER), 2003; Sayuti, 2010; Ministry of Manpower and Transmigration Republic of Indonesia, 2009). PjBL implementation develops $21^{\text {st }}$ century skills such as collaboration, communication, critical thinking, and technology usage, as well as other critical abilities necessary to succeed at workforce (Larmer \& Mergendoller, 2010) A meaningful learning environment increases the students' expertise in project organizing, team cooperation, professional responsibility ( $\mathrm{Du} \&$ 
Kolmos, 2006), critical and creative thinking, and generic capability of VHS (Luthvitasari, Made, \& Linuwih, 2013).

This study describes (1) the project planning implemented by VHS teachers using the $\mathrm{PjBL}$ model, including project characteristics and industrial involvement, (2) the implementation of the model, (3) the evaluation of learning implemented, including the type of evaluation and involvement of students; and (4) the development of the $21^{\text {st }}$ century workforce character, including the types of character values and their integration in vocational learning.

\section{METHOD}

\section{Design}

This study uses a combination of quantitative and qualitative research methods with a sequential explanatory technique (Creswell, 2009). Quantitative research was conducted to identify and describe various project planning, PjBL implementation, and project evaluation by teachers. Also, it was meant to describe the 21 st-century workforce character values and their integration patterns in learning. Qualitative research deepened and detailed the quantitative research findings, particularly on the project planning process, the entire $\mathrm{PjBL}$ syntax, and $21^{\text {st }}$-century workforce character development patterns in vocational learning. The sequential explanatory research has seven steps, including (1) literature studies on PjBL and workforce character development for the $21^{\text {st }}$ century and its synthesis, (2) quantitative research implementation (data collecting up to the analysis), (3) qualitative research implementation (data collecting up to the analysis), (4) synthesis of quantitative and qualitative research results, (5) interpretation from the theoretical study and quantitative and qualitative research to construct the implementation model and workforce character development in the $21^{\text {st }}$ century, (6) FGD with VHS teachers about the implementation of the PjBL model and the development of $21^{\text {st }}$-century workforce character, and (7) formulating various implementations of the model and workforce character development in $21^{\text {st }}$ century in VHS with Mechanical Engineering Study Program.

\section{Subject}

The subjects in the quantitative research were 60 teachers from 11 schools that implement PjBL in Malang City and Regency, Blitar City and Regency, and Pasuruan Regency. The subjects in qualitative research were selected based on their job status and answers in the open questionnaire. On job status, the teachers served as Chairs of the Mechanical Engineering Expertise Program. Furthermore, the selected teachers' answers showed their complexity in project planning and teaching implementation similar to the PjBL theory. A minimum and maximum of two and four subjects were selected from each school based on competency in each VHS. All FGDs were conducted in each VHS, and all teachers involved in quantitative and qualitative researches joined as participants. 


\section{Data Collection and Analysis Techniques}

At the quantitative research stage, data collection used structured and unstructured questionnaires developed based on the literature study on the PjBL model at VHS. The questions cover project characteristics, implementation, learning assessment, and workforce character development of the $21^{\text {st }}$ century. The use of structured and unstructured questionnaires was adjusted to the characteristics of the research variables to be measured. Each variable used one of the two types of questionnaires or even both at the same time. In the qualitative research, data was extracted from in-depth interviews, non-participatory observation in the learning process, and study in various documents, including lesson plans, job sheets, project proposals, and students' reports. Guidelines of interviews, observations, and studies on learning documents were developed based on the information from quantitative research. Interviews were conducted face-to-face, using mobile phones, and taking notes as well as recording the teacher's voice. Observations were carried out by directly looking at the vocational learning process at VHS, taking notes and recording the important details. The documents' review involved reading the sample of teachers' lesson plan documents, worksheets for the practicum, proposals, and project reports of students, and noting important details contained.

Data from the structured questionnaire in quantitative research were analyzed with descriptive statistics. However, the data from the unstructured questionnaire and qualitative research were analyzed using qualitative analysis techniques. The details from the unstructured questionnaire and qualitative research were considered similar. Importantly, the qualitative analysis was based on Boulton \& Hammersley (2006). The $\mathrm{PjBL}$ implementation models were constructed through synthesis integration of theoretical studies and results. Furthermore, the results of the construction of the PjBL implementation models were taken to the FGD forum in each school to obtain input and clarify their use from the teachers involved in the study. There were two instruments used in the FGD, including open-ended and structured questions to accommodate input from teachers and measure their tendency to implement the PjBL models constructed. Overall, the research data were collected from July to November 2018.

The never-ending implementation of observations from the beginning to the end of the vocational learning process is the main weakness of this study. This is because the implementation of vocational learning takes long, approximately six hours each day.

\section{FINDINGS}

\section{Project Planning}

Projects planned by teachers range from simple to complex and functional workpieces. The complexity depends on the broad-narrow scope of basic competencies (BC) used as a reference in project planning. The simplest workpieces are produced from one $\mathrm{BC}$ in certain subjects. In contrast, the most complex workpieces are produced from several BCs through cross-subject, cross-expertise competencies (EC), and cross-expertise programs (EP). The analysis of the job sheets for the practicum shows that the 
workpieces for students range from very simple to very complex, mainly appropriate technologies. Figure 1 shows the complexity of the form of projects planned by the teacher $(n=60)$. The level of the complexity of the project $(\mathrm{PC})$ planned by the teachers is PC3 $31.67 \%$, PC2 and PC4 23 and 33\% respectively, PC1 13.33\%, and PC5 $8.33 \%$.

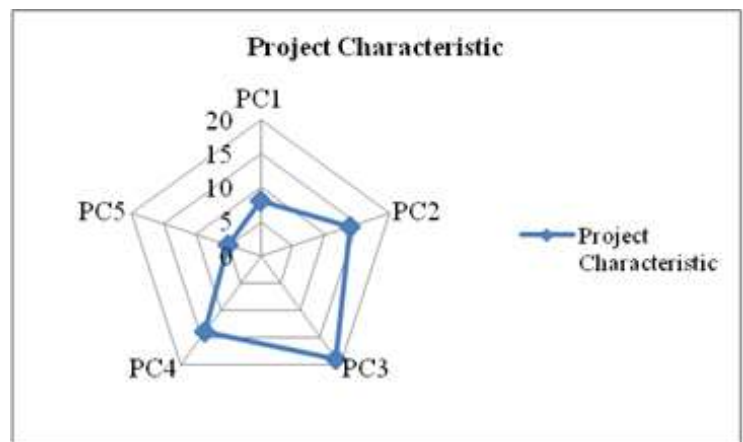

Figure 1

Project Characteristics Planned by the Teachers

PC1: Project formulated from one BC in one subject.

PC2: Project formulated from several BCs in one subject.

PC3: Project formulated from several BCs in several subjects in one EC.

PC4: Project formulated from several BCs from several subjects cross-EC but in one EP.

PC5: Project formulated from several BCs in several subjects in cross-EC and cross-EP.

The results showed that most projects were results from several BCs in several subjects within one particular EC, and there was a small portion of the projects created from several BCs from several subjects in cross-EC and cross-EP. Industrial involvement in project planning is shown in Figure 2.

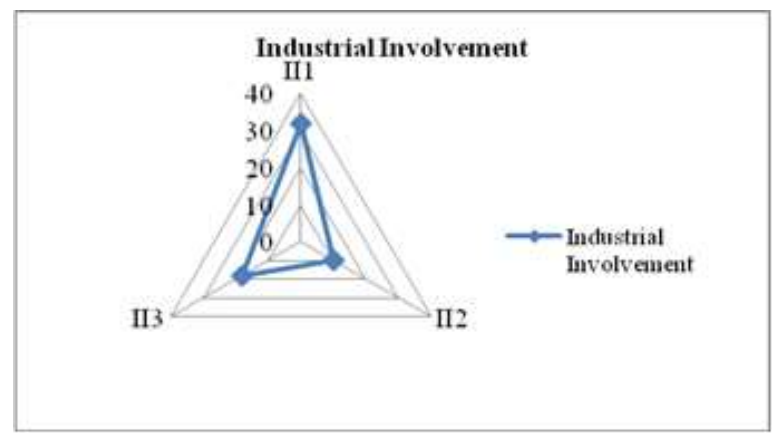

Figure 2

Industrial Involvement in Project Planning

II = Industrial Involvement

Figure 2 shows that (1) more than half of the teachers did not involve industries in project planning $(\mathrm{II} 1=53,33 \%)$; $(2)$ some teachers engage the industries through ordering products (projects) in the form of shop drawings (II $2=16,67 \%$ ); and (3) some 
teachers engage the industries as the validator from the products ordered descriptively (II3 $=30,00 \%$ ). Related to the involvement of students in project planning, only a partial teacher $(23.33 \%)$ involve the students. About $76.67 \%$ of the teachers do not involve students.

In project planning, important information from the teachers was obtained through indepth interviews. This includes (1) the teacher project is a means of students learning to achieve BCs, and therefore, the complete mastery of content is imperative for students, not the achievement of the project itself, (2) simple projects developed based on one or several BCs from one particular subject is given to class $\mathrm{X}$ students whose practice activities are still classified as basic, (3) complex projects include several BCs from various subjects in a particular EC given to class XI students; (4) complex projects include several BCs from various cross-EC subjects and cross-EP given to class XII students; (5) all complex projects are functional workpieces, though not all are worth selling, (6) projects obtained from partner industries/institutions are generally classified as complex and cross-EC and cross-E, (7) for schools that develop superior products, the project is designed based on predetermined superior products, such as electric bicycles, where the planning process is carried out by teachers in cross-EP and the production process by students in cross-EP, (8) all industrial order projects and school superior products are in the form of appropriate technology and/or other commercial commodities eligible for sell, (9) industrial involvement in project planning is limited and temporary, and (10) the involvement of students in project planning is also minimal and only involve making 3D and work drawings through technical drawing lessons based.

\section{PjBL Implementation}

PjBL was implemented by teachers in three patterns as shown in Figure 3. From Figure 3 , the sequential pattern of PjBL implementation used is IP2 55.00\%, IP1 28.33\%, and IP3 $16.67 \%$. The IP1 is the PjBL implementation pattern where the learning started with theoretical material, followed by a demonstration in machine operational, training assignment, and assessment of product/training results. In the IP2, learning was started by giving theoretical material, followed by machine operation demonstration, training assignments, project presentation, project execution in groups, making a report, and assessment of results/product. The IP3 is the implementation pattern where learning began by giving theoretical material, then machine operation demonstration by the teachers, training assignments, project delivery, preparation of project proposals by a group of students, project execution in groups, product assembling, making project reports, and assessment of results. Qualitative research findings through observation of the vocational learning implementation reinforce these quantitative findings, where the IP1 pattern is used by all teachers in basic vocational learning in class X. The IP2 and IP3 patterns are used by teachers in vocational learning in classes XI and XII. However, some teachers use the IP2 pattern up to class XII. 


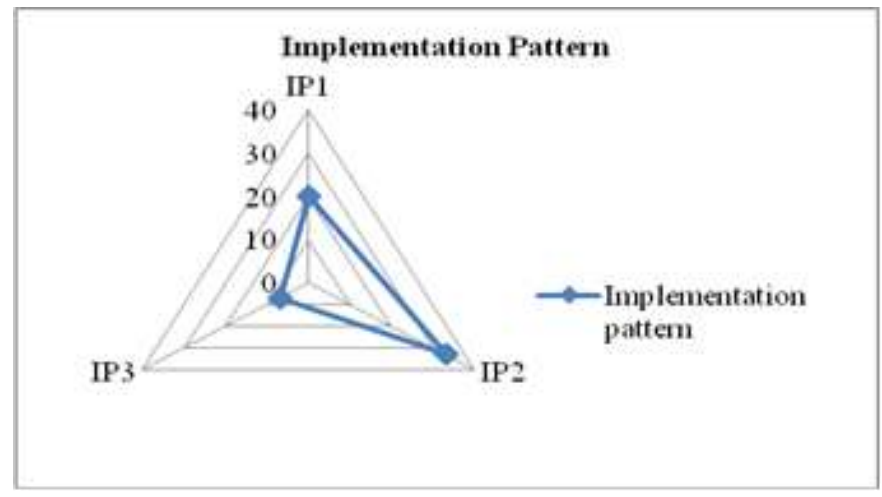

Figure 3

Implementation Pattern of PjBL by the Teachers

IP = Implementation Pattern

The synthesis of various theoretical studies resulted in four implementation models of the PjBL in the Mechanical Engineering Study Program of VHS, including the pre$\mathrm{PjBL}$, the simple, the industrial order, and the school's featured product. The implementation of the four PjBL models by teachers confirmed quantitatively in the FGD activities is shown in Figure 4.

The Pre-PjBL with similarities to the Training Within Industry (TWI) model were implemented by teachers $(33,33 \%)$. The main characteristics include (1) project is formulated from $1 \mathrm{BC}$ in 1 specific subject, (2) it is presented in the form of shop drawing, (3) emphasizes in BC mastery learning, do not consider the usefulness of the products, and students execute the project individually. The second is the simple PjBL models that have the main characteristics including: (1) the project is formulated based on several BCs within various subjects in a specific expertise competency, (2) a particular function, (3) presented in drawing format in the job sheet, (4) an execution procedure, (5) students make a written report, and (6) implemented in groups. The second was implemented by $28,33 \%$ of the respondents. 


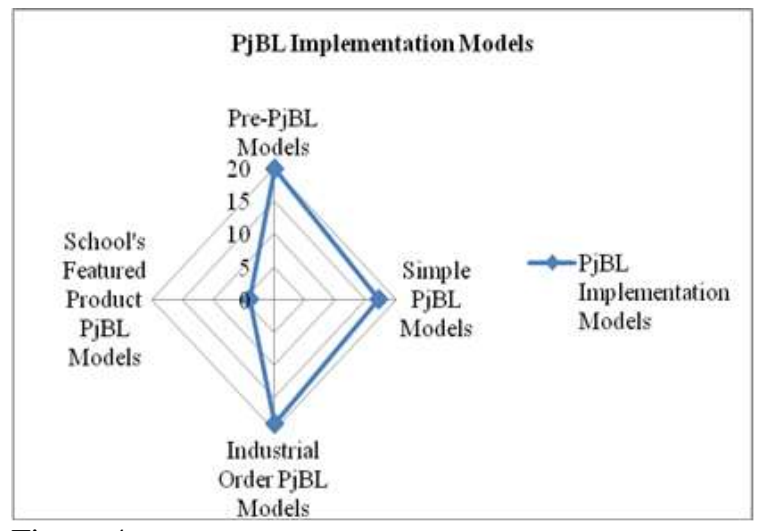

Figure 4

The Implementation Models of PjBL

The third model is the PjBL industrial order which is divided into two models. This includes the one in which the orders from the industries or partner institutions is in the form of shop drawing implemented by $15 \%$ of teachers. There is also a model in which the orders from the industries or partner institutions include product descriptions implemented by $16.67 \%$ of teachers. The model in which the orders from the industries or partner institutions is in the form of shop drawing has similarity with the second model . Additionally, the $\mathrm{PjBL}$ in which the orders from the industries or partner institutions is in the form of product description has the following characteristics: (1) project was formulated by a team of teachers from various cross expertise competence subjects based on the order of the industry/partner institutions, (2) generally, the project is based on appropriate technology, (3) the project was formulated in the form of shop drawing in the job sheet; (4) it was implemented by students from various subjects, (5) students made a proposal following the applied parts that covered project title, shop drawing, required material, used tools, work procedure, work schedule, and work safety, (6) project execution process, where each group of students work on the project following established procedures; (7) assembling process of final product from the parts that each group executed, (8) students wrote written report; and (9) students were involved in the final product assessment.

In the fourth $\mathrm{PjBL}$ model, projects that students have to work on are in the form of school's featured products, such as Electric School Bikes (ESB). The characteristics include (1) teachers design the project from sketching, initial design, and final design, (2) project was in the form of shop drawing with dimensions in the job sheet, (3) it was implemented in groups from various cross-competency subjects and expertise programs, (4) project proposals were made following the executed parts, including the project title, shop drawing, required materials, used tools, and work procedure, schedule, and safety, (5) students work on the project according to established procedures:(6) the final product is assembled based on the implemented parts. (7) students made written reports, 
and (8) students were involved in the final product assessment. This model was conducted by only $6.67 \%$ of teachers.

The implementation of the third and fourth models is consistent with the proposals and project reports. The results of the analysis of the two documents showed that (1) the assignment was in the form of working drawings, (2) students work in teams; (3) a project proposal contains (a) the name of the project/sub-project, (b) working drawing, (c) materials, (d) equipment, (e) work process, and (f) work safety, (4) the results of the project must be assessed (5) a project report includes the proposal component plus the results, and an analysis of the project's process and results; and (6) students must present their project reports.

From the FGD activities, the following information was obtained: (1) teachers from various VHS stated that three of the four PjBL implementation models were in line with their approaches. An implementation pattern was a combination of the TWI and the models, (2) the fourth model can only be applied by schools that have established superior products/projects; (3) industrial involvement in the implementation of $\mathrm{PjBL}$ model is conducted passively, meaning teachers are only waiting for orders from industry rather than actively asking for jobs from industry, and (4) three important components that teachers emphasize to students include: (a) the preparation of project proposals, (b) the project execution process, and (3) the preparation of project reports.

\section{PjBL Evaluation}

The evaluation pattern showed that all teachers evaluated the processes and products. In the evaluation, half of the respondents involved students. The evaluation (1) only involved a teacher and not students $(3.33 \%)$; (2) was conducted by a team of teachers but did not involve students $(6.67 \%)$; (3) conducted by a teacher and involved students (30.00\%); (4) was held by a team of teachers with students' involvement (18.33\%); (5) was conducted by a teacher with students involvement, where they assessed their project and other group's projects $(8.33 \%)$, (6) held by a team of teachers with students involvement, where they valued all the projects $(33.33 \%)$. The involvement of students in the evaluation was justified through random interviews. The following are some of the assertions from students (1) "... Yes, students are involved. My friends and I in one group were asked to assess the products we produce. Also, we were asked to assess the products of other groups "; (2) "... Here the assessment involves students, sir. I was given a format by the teacher and asked to assess my products and those of friends "; (3) "... Depending on the teacher, some involve, some don't ... "; (4) "... Usually, only the teacher assesses the results of our practice. Students are rarely involved .... ".

\section{$21^{\text {st }}$ Century Workforce Character Development}

In the Mechanical Engineering Expertise Program, most teachers $(73.33 \%)$ argued that the workforce character development for the $21^{\text {st }}$ century is very important for the students while the remaining (26.67\%) stated it to be important; (2) all teachers (100\%) reported that the development of characters was by design. However, $68.33 \%$ said it was integrated into the learning process, though not listed in the lesson plan. The rest stated that it was incorporated during the learning process, and (3) there are 10 characters of 
the workforce for the $21^{\text {st }}$ century important for development, including work safety, positive attitude and behavior, teamwork, adaptation, participation in projects and tasks, communication, responsibility, thinking and problem solving, information processing, and continuous learning.

The lesson plan document analysis shows that there is little evidence on the effective formulation of the values of $21^{\text {st }}$-century workforce characters. Partially, the formulation of workforce character values can be reflected in learning objectives. For instance, through group work in lathe machining practicum, students are expected to demonstrate work safety, teamwork, adopt the SOP, and produce workpieces as assigned in the job sheet. The objective formulation contained three aspects of work safety, work well together, and adopt the SOP.

The interviews showed teachers were aware of the importance of developing the workforce character of the $21^{\text {st }}$ century to students. Although they did not include it in the lesson plan, students were always taught good work characters. The following excerpt shows the assertion of one of the teachers "... Also, there is an element of attitude, which is the character of work. It includes safe work and a responsible attitude. Everything should be developed through vocational learning ... ".

\section{DISCUSSION}

\section{Project Planning Characteristics in PjBL Model at Mechanical Engineering Expertise Program VHS}

Based on quantitative and qualitative studies, the characteristics of the project designed by the vocational teachers include the manufacture of certain products from simple to complex workpieces. This finding follows the project characteristics of mechanical engineering (Han \& Bhattacharya, 2010). Al-sharif (2015) defined mechanical engineering as a practical project, specifically workpieces carried out in laboratories or workshops in VHS. The PJBL model with such characteristics is referred to as the operationalization of the concept of production-based education in VHS (Sumarni, 2015). Knowledge and skills are used to solve complex problems in product manufacturing practices (Hârtescu, 2014).

There are two broad classifications of the project from the planning process standpoint, including: (1) half vocational teachers that did not involve industry/partner institutions at all, and (2) those who involved the industry/partner institutions in various capacities. The first classification was found in VHS with only one expertise program. Generally, the project selected by teachers can be divided into three, they are: (a) workpieces developed from a particular subject; (b) projects prepared from various subjects in a specific expertise competency, such as teachers of Lathe Machining, Milling Machining, or SMAW Welding Techniques, and (c) developed from various subjects cross expertise competency or programs. Generally, a workpiece from the 'a' group is only for training but not functional in life. Contrastingly, the workpieces from ' $b$ ' and 'c' have specific functions in everyday life. The project's classification is in line with Mills \& Treagust (2003a), which called it a small and large scale project. 
The projects that involved industries or partner institutions can be grouped into two types, including industrial or partner institutions' involvement as the (a) customer that orders shop drawing, and (b) the customer that orders the desired product description. The project planning involving an industry or a partner institution is based on Zhang (2013). They consisted of project selection, modification, and finishing. In this context, planning from the VHS teachers is appropriately called project selection based on the industry or partner institution.

In Public VHS 1 Purwosari, Pasuruan Regency, teachers from cross-subjects and crossexpertise programs planned the featured program of the school, specifically the Electrical School Bike. The school was the partner institutions of the teachers, and therefore, the project followed the PjBL qualification from Zhang (2013) and Mills \& Treagust (2003b). The peculiarity of the project involved productive teachers form Expertise Competency of Welding Engineering, Machining Technique, Mechatronics Engineering, and Automotive Body Repair Techniques with different portions.

PjBL Implementation Models at Mechanical Engineering Expertise Program VHS

There are three classifications of PjBL implementation including (1) pre-PjBL, (2) PjBL with a simple project and (3) $\mathrm{PjBL}$ with a real project. Pre-PjBL is marked by training assignments to make products that do not meet the requirements of a project. However, it still uses the training techniques rather than project-based learning, where the syntax or pattern has similarities with the TWI (Training Within Industry) model (Nölker \& Schoenfeldt, 1983). The syntax consists of preparation, demonstration, imitation, practice, and assessment. Therefore, this model is called Pre-PjBL because the workpieces used does not meet the requirements as a project. Also, the learning pattern or syntax is still classified as training and teacher-centered.

The second classification is $\mathrm{PjBL}$ with a simple project. The main difference between this model with the previous one is on the project characteristic. It was created or planned based on several BCs within various subjects in a particular expertise. The project also has a higher complexity compared to the training assignment. The project has specific functions, though with limited usage. Also, it has different learning syntax with the previous model and involves students in drafting the work procedure, project finishing, and developing reports. The learning pattern of this second model is the same as the second implementation pattern (IP2) explained before.

The third model is PjBL with a real project. There are three classifications as follows, (1) order from the industry or partner institution of the VHS in the form of shop drawing, (2) request from the industry or partner institution in the form of product description; and (3) a featured product from the school. The project planning from the second and third classification was conducted by the vocational teachers from different subjects related to the project, leading to shop drawing from each product's part. The shop drawing was sorted into a sub-project based on the subjects involved in the process.

After sub-project implementation, project assembling was conducted to create the desired final product. During assembling, there was cooperation, discussion, 
negotiation, modification of dimensions, and rework of certain groups in case of an incorrect size between the components with one another. Once assembling was complete, report drafting started. Lastly, students assessed the products and closed with the presentation from each group based on the drafted report. The learning pattern of this third model is the same as the third implementation pattern (IP3) and the model syntax developed by Jalinus et al. (2017).

The characteristics of the PjBL model with real projects cover not only one subject but also cross-subjects, cross expertise competency, and cross expertise programs. Based on Mills \& Treagust (2003b), this project had more multidiscipline. The learning activity during project implementation was relatively long, one semester on average. This in line with Han \& Bhattacharya (2010), which stated that PjBL learning is complicated, requires several steps and a long duration.

The learning process in the model with real projects showed a complex process and involved students' autonomy in product making. This is in line with Thomas, Mergendoller, \& Michaelson (1999), which stated that students in PjBL are involved in problem-solving and meaningful tasks, giving them a chance to work independently, leading to a realistic product-making. All products created in $\mathrm{PjBL}$ with real projects have functions and usages in real life.

The development of $\mathrm{PjBL}$ implementation in this research was closely related to the project-based model configuration developed by Waras (2010). Model I has relatively similar characteristics with the first configuration by Waras. A project-based learning model prioritizing project work was referred to as a vehicle for developing technical skills. The dominance of the teacher's role in the process of completing project work is enormous. For instance, project-based learning was conducted in a subject and supervised by a teacher, and the project tends to be mono-discipline (Waras, 2010).

Model II have relatively similar characteristics with the second configuration by Waras (2010). Specifically, project learning positioned projects work as a vehicle to learn theories and practice, though a teacher still has a high control in the finishing project. There are various similarities, including: (1) project is relatively complex and involves more than one subject, (2) students do not draft the project proposal, and (3) students are not involved in the assessment. Model III and IV have similar characteristics with the third project learning model configuration by Waras (2010). The similarities include: (1) the project theme or title is taken from an industrial context or another community environment, (2) interdisciplinary project, (3) students work in groups, draft the project or sub-project proposal, participate in the assessment process, and have the chance to present their projects. The only characteristic that differentiates the Model III and Model IV from Waras (2010) is the assembling of the sub-project conducted by each group from different subjects. The difference occurs because Waras (2010) researched VHS with various expertise programs while this research only used the Mechanical Engineering Expertise Program which focuses on making a product (Han \& Bhattacharya, 2010; Allison, 2018; Al-sharif, 2015; Hârtescu, 2014; Sumarni, 2015). 
All teachers had evaluated the learning process and summative evaluation of the project products by involving students. This is in line with Zhang (2013), which states that project evaluation is carried out in two steps; process and summative evaluation involving groups of students.

\section{Development of $21^{\text {st }}$ Century Workforce Character at Mechanical Engineering Expertise Program VHS}

Little evidence show that the workforce character for the $21^{\text {st }}$ century was designed for development in the lesson plan and in classroom learning activities. Also, there was little proof that teachers' lesson plans aimed to develop the workforce character for the students. One of the teachers stated that the most important thing is teaching, and therefore, planning should be made simple. The important thing is that the components in the lesson plan are filled, though teaching should be effective. Similarly, the laboratory observation showed that in the beginning, teachers should always emphasize the importance of work safety and ask students to work according to work safety. During practice, students should be reminded to coordinate and cooperate with other groups. However, each group is responsible for their work but accountable for the final product produced together. During the presentation, teachers reprimand and remind students of behavior and attitude, instructing them to communicate using the proper and correct language. These learning events contain at least five values of workforce character of the $21^{\text {st }}$ century, including work safety, cooperation, responsibility, participation in projects, and good communication.

The discussion shows that vocational teachers have a high commitment to develop various values of $21^{\text {st }}$-century workforce character. This can be achieve through the implementation of the PjBL model in vocational learning. It is in line with various theoretical and empirical studies on the potential of the PBL model (see Sukamta et al., 2018; Samsudi et al., 2019), Various workforce character values are also in line with the expectations of experts and various institutions related to employment (Sayuti, 2010; Secretary's Commission on Achieving Necessary Skills, 2000; National Centre for Vocational Education Research (NCVER), 2003; Ministry of Manpower and Transmigration Republic of Indonesia, 2009).

\section{CONCLUSIONS}

The project planning carried out by VHS teachers in implementing the PjBL model can be described as follows: (1) planned projects have various characteristics, including (a) formulated from the simple to complex workpieces with certain functions and are worthy of sale, (b ) simple projects are formulated from one or several basic competencies in one particular subject. Contrastingly, complex projects are formulated from several basic competencies in various subjects in cross-expertise competencies or cross- programs, (2) some of the projects were formulated by a team of vocational teachers from certain VHS and industries; and (3) most projects were formulated without involving students.

The implementation of the model implemented is characterized by (1) three classifications, including (a) Pre-PjBL, (2) simple project, and (3) the model with the 
real or complex project. The pattern or syntax is a combination of the TWI and $\mathrm{PjBL}$ models. The Pre-PjBL is characterized by learning preparation, demonstration, imitation, practice, and assessment. Similarly, the model with the simple project is characterized by theoretical material, demonstration, and training assignments, project presentation. Moreover, the model with the real or complex project involves giving theoretical material, demonstration, training assignments, project delivery, preparation of proposals by groups of students, project execution in groups, product assembling, making project reports, and assessment of results/products.

The evaluation of learning conducted includes process and product evaluation. A small portion of its implementation involves students, which is only limited to product evaluation.

The $21^{\text {st }}$-century workforce character developed by vocational teachers include work safety, positive attitude and behavior, work with others, adaptation, participation in projects and tasks, communication, responsibility, thinking and problem solving, information processing, and continuous learning. Although they do not always include them in the lesson plan, teachers always try to develop a variety of $21^{\text {st }}$-century workforce character in an integrated way.

\section{REFERENCES}

Aalborg University. (2010). Principles of problem and project based learning. In The Aalborg PBL model. Harvard University. Retrieved from www.aau.dk

Al-sharif, L. (2015). Project Based learning in undergraduate engineering education. Paper presented at the Professional Accreditation Conference for Engieers. At Amman, Jordan.

Allison J. M. (2018). Project based learning to promote 21st century skills. (Unpublished doctoral dissertation). The College of William and Mary in Virgina.

Basilotta Gómez-Pablos, V., Martín del Pozo, M., \& García-Valcárcel Muñoz-Repiso, A. (2017). Computers in human behavior project-based learning (PBL) through the incorporation of digital technologies: An evaluation based on the experience of serving teachers. Computers in Human Behavior, 68, 501-512. https://doi.org/10.1016/j.chb.2016.11.056.

Boulton, D., \& Hammersley, M. (2006). Analysis of unstructured data. In S. roger, J. Victor (Eds.), Data collection and analysis (pp.243-259). London: SAGE

Chiang, C. L., \& Lee, H. (2016). The effect of project-based learning on learning motivation and problem-solving ability of vocational high school students. International Journal of Information and Education Technology, 6(9), 709-712.

Creswell J. W. (2009). Research design: Qualitative, quantitative, and mixed methods approaches. Thousand Oaks, California: SAGE Publications, Inc. 
$\mathrm{Du}, \&$ Kolmos. (2006). Process competencies in a problem and project based learning environment. In P. Anderson, \& C. Borri (Eds.), SEFI Annual Conference: Engineering education and active students (pp. 1-13). Samlignsnummer för enstaka enskilt utgivna arbeteb.

Han, S., \& Bhattacharya, K. (2010). Constructionism, learning by design, and project based learning. In M. Orey (Ed.). Emerging perspectives on learning, teaching, and technology, 1-18. University of Georgia.

Hârtescu, I. (2014). Providing technology support for project-based learning. Advances in Social Science, Education and Humanities Research, 226, 607-618.

Jalinus, N., Nabawi, R. A., \& Mardin, A. (2017). The seven steps of project based learning model to enhance productive competences of vocational students. Advances in Social Science, Education and Humanities Research, 226, 251-256.

Larmer, J., \& Mergendoller, J. R. (2010). Seven essentials for project-based learning. Educational Leadership, 68(1), 34-37.

Law of The Republic of Indonesia Number 9 of 2016 on Prevention And Resolution of Financial System Crisis By The Blessings of Almighty God The President of The Republic of Indonesia. (2016).

Luthvitasari, Made, \& Linuwih. (2013). Implementasi Pembelajaran Berbasis Proyek Pada Keterampilan Berpikir Dan Kemahiran Generik Sains. Innovative Journal of Curriculum and Educational Technology, 2(1), 159-164.

Menakertrans. (2009). Keputusan Menteri Tenaga Kerja dan TransmigrasiRe-publik IndonesiaNo. Kep.227/MEN/2003 Tahun 2003 tentang Tata Cara Penetapan Standar Kompe-tensi Kerja Nasional Indonesia (SKKNI). Jakarta: Menakertrans.

Mills, J. E., \& Treagust, D. (2003a). Engineering education - is problem-based or project-based learning the answer. Australasian J. of Engineering Education, 3, 2-16.

Mills, J. E., \& Treagust, D. F. (2003b). Using projects to teach structural engineering. Australian Journal of Structural Engineering, 4(3), 211-220. https://doi.org/10.1080/13287982.2003.11464921.

National Centre for Vocational Education Research (NCVER). (2003). Defining Generic Skills. NCVER. Adelaide.

Nölker, H., \& Schoenfeldt, E. (1983). Formación profesional_enseñanza, currículom, programación. Jakarta: Pendidikan Kejuruan : Gramedia.

Permendikbud. (2016). Peraturan Menteri Pendidikan dan Kebudayaan Nomor 22 Tahun 2016 Tentang Standar Proses Pendidikan Dasar dan Menengah. Jakarta: Permendikbud. 
Prince, M. J., \& Felder, R. M. (2006). Inductive Teaching and learning methods: definitions, comparisons, and research bases. Journal of Engineering Education, 95(2), 123-138. https://doi.org/10.1002/j.2168-9830.2006.tb00884.x.

Samsudi, Supraptono, E., Sunyoto, \& Rohman, S. (2019). The implementation of project-based learning in productive skill programs for the development of 21 st century vocational school students. UNNES International Conference on Research Innovation and Commercialization, 470-479. https://doi.org/10.18502/kss.v3i18.4738.

Sayuti, M. (2010). Keterampilan Generik Dalam Kurikulum Smk: Proposal Untuk Membangun Karakter Siswa Smk, pp. 1-8.

Sukamta, S., Florentinus, T. S., Ekosiswoyo, R., \& Martono. (2018). Project based learning enhances student quality in vocational education. Advances in Social Science, Education and Humanities Research, 247, 479-483.

Sumarni, W. (2015). The strengths and weaknesses of the implementation of project based learning: A Review. International Journal of Science and Research (IJSR), 4(3), $478-484$.

The Conference Board of Canada. (2000). Employability skills. Retrieved from http://conferenceboard.ca/nbec

The Secretary's Commission on Achieving Necessary Skills U.S. Department of Labor. (2000). U.S. Department of Labor. A Scans Report for America. Retrieved from https://wdr.doleta.gov/SCANS/whatwork/whatwork.pdf.

Thomas, J. W., Mergendoller, J. R., \& Michaelson, A. (1999). Project-based learning: A handbook for middle and high school teachers. Novato: The Buck Institute for Education.

Viswambaran, V. K., \& Shafeek, S. (2019). Project based learning (PBL) approach for improving the student engagement in vocational education. Advances in Science and Engineering Technology International Conferences (ASET), 1-8.

Waras. (2009). Active Learning di antara Idealisasi dan Realitas Praktik Pendidikan. “ Peningkatan Kualitas Pembelajaran Melalui Active Learning Menuju Profesionalisme Guru" di UNS Surakarta. Seminar Nasional VII Pendidikan Biologi, 1-12. Retrieved from https://eprints.uns.ac.id/14333/1/1524-3351-1-SM.pdf.

Waras. (2010). Implementasi Project-Based Learning di Sekolah Menengah Kejuruan. Jurnal Pendidikan dan Pembelajaran, 17(I), 98-110.

Yudiono, Pramono, \& Basyirun. (2019). The Hypothetic model of integrated production-based learning with the $21 \mathrm{st}$ century learning skills in mechanical engineering. Jurnal Pendidikan Teknologi dan Kejuruan, 25(1), 97-102. https://doi.org/10.21831/jptk.v25i1.23328. 
Zhang, Z. (2013). Application of project-based learning in teaching of the curriculum of combining study with work of higher vocational education. Advances in Intelligent Systems Research, 724-727. https://doi.org/10.2991/icetis-13.2013.165. 